\title{
Trust and the role of the public library in the integration of refugees: the case of a Northern Norwegian city
}

Andreas Vårheim, University of Troms $\varnothing$

Accepted Author Manuscript (post-print)

of

Vårheim, A. (2014). Trust and the role of the public library in the integration of refugees: The case of a Northern Norwegian city. Journal of Librarianship and Information Science, 46(1), 62-69. doi:10.1177/0961000614523636

\begin{abstract}
This article discusses how public libraries contribute to the generation of social capital and social trust among refugees participating in library programmes while enrolled in a compulsory government introductory programme to Norwegian language and society. The students' experiences with the library have made them more trusting toward the institution of the public library and library patrons in general. Complementing earlier studies, the paper shows that library programmes for immigrants can contribute to the creation of social trust. Library programmes can play an important part in facilitating and speeding up trust-creating processes, making integration less traumatic, although trust in unknown people (generalized trust) remains low, before, during, and after the completion of the programmes.
\end{abstract}




\section{Keywords}

Public libraries, social capital, social trust, immigrants, refugees

\section{Trust, immigration, and public libraries}

Western societies face increased migration from Third World countries. The successful integration of immigrants appears to be important for continued prosperity and working democratic governments. Wealth, democracy, uncorrupt public institutions, and healthy and happy populations, originate in countries with high levels of trust in strangers (generalized trust) and social capital. Generalized trust among natives, as among immigrants, is a strong indicator of successful integration (Putnam, 2007; Kumlin and Rothstein, 2010; Dinesen, 2011). Most research on social trust and the associated concept of social capital has found that ethnic diversity in the population drives down levels of trust (Alesina and La Ferrara, 2000, 2002; Coffe and Geys, 2006; Costa and Kahn, 2003; Delhey and Newton, 2005; Putnam, 2007). In the United States, immigrants from low-trust societies have low levels of social trust upon entry, and trust continues to remain low also for their offspring (Algan and Cahuc, 2010; Klesner, 2003).

However, this gloomy picture is modified in many newer studies. Recent research indicates that immigrants, at least in western Europe, adapt to a level of generalized trust not far below natives over two generations (Dinesen, 2010). Studies also show that well-functioning and impartial public institutions increase levels of trust among immigrants (Kumlin and Rothstein, 2010), and that contact across ethnic groups reduces prejudice (Pettigrew et al., 2011). Public libraries are public 
institutions with characteristics that have positively influenced the trust levels of immigrants attending library programmes in American southwestern states (Vårheim, 2011; Vårheim, under review). This paper investigates whether this is the case for refugees attending public library programmes while they are enrolled in a compulsory introductory programme to Norwegian language and society organized by Norwegian immigrant authorities.

\section{Theoretical and empirical contributions}

Theoretically and empirically this paper adds to the research agenda on public libraries, ethnicity, and social trust. Theoretically it argues that among public institutions - public libraries in particular - contribute to increased generalized trust, a core component of social capital, among immigrants. Empirically, in an explorative study trust patterns among immigrant library users participating in a compulsory introductory programme on Norwegian language and culture skills for immigrants were analyzed.

Both informal social contacts and specific institutional settings can have positive effects for the generalized trust of immigrants. Several recent studies found that neighborhood contact between diverse ethnic groups creates trust effects for immigrants (Kumlin and Rothstein, 2010; Marschall and Stolle, 2004; Stolle et al., 2008), while segregated neighborhoods had negative effects (Uslaner, 2010). Fair and impartial public institutions that treat people equally have been found in many studies to influence generalized trust (Dinesen, 2011; Kumlin and Rothstein, 2005, 2010; 
Rothstein and Stolle, 2008), and Kumlin \& Rothstein found that this positive effect is particularly significant for immigrants (2010).

Public libraries are highly trusted universalistic institutions visited by a wide spectrum of people. A nationwide Swedish survey found that among a variety of public services, public libraries came second in terms of trust; only health institutions were more trusted (Höglund and Wahlström, 2009: 19). The results of two Norwegian surveys (in 2006 and 2011) on the population of Oslo and Tromsø showed that public libraries were the most trusted public institutions, while the police were ranked second. ${ }^{1}$ Similarly, Australian data has revealed that $98.7 \%$ of respondents in a survey held that public libraries were safe places (Cox et al., 2000: 29).

As they are highly trusted institutions, public libraries could be well suited as settings for trust-building through informal contacts between patrons who do not know each other. While it turns out that most intergroup contact will reduce prejudice and increase trust (Pettigrew et al., 2011; Pettigrew and Tropp, 2011), the processes are strengthened when followed by "[e]qual group status within the situation; common goals; intergroup cooperation; and the support of authorities, law, or custom" (Pettigrew, 1998: 65). Negative contact effects typically happen in situations when people feel threatened by the other party and the contact was involuntary.

Public libraries probably have more contact-facilitating properties than most other venues, including other universalistic welfare-state institutions. However, public libraries can never be a panacea to problems of intergroup conflict. Structural socioeconomic policies that promote equal access to education, work, and housing, and therefore combat segregation are of primary importance. Yet, as low-threshold local community meeting places (Aabø et al., 2010; Audunson et al., 2011), libraries are part of this infrastructure. They are places where patrons from different ethnic groups 
can at least observe or engage more intensively with each other over a prolonged period of time. Contact theory research suggests that the more intense behavioral engagement is between groups, the more prejudice is reduced (Pettigrew et al., 2011). By placing a public library branch between two segregated communities in Chicago, city planning authorities designed an intergroup hub that seemed to be and certainly could be a starting point for intergroup trust and community integration (Putnam et al., 2003). The few studies conducted on the role of public libraries in the lives of immigrants found that libraries facilitate and create contact between groups, for example between majority groups and minority groups and satisfy the basic information needs of newcomers (Elbeshausen and Skov, 2004; Fisher et al., 2004; Caidi and Allard, 2005; Audunson et al., 2011).

Likewise, the literature on the extent to which public libraries create trust is scarce (Vårheim et al., 2008; Johnson and Griffis, 2009; Johnson, 2010; Vårheim, 2011; Johnson, 2012; Vårheim, under review; for an overview of the pre-2007 literature, see Vårheim (2007)), and in relation to immigrants and social trust, even more so (Vårheim, 2011; Vårheim, under review). Vårheim (2011) interviewed U.S. public library directors on the effects of library programming as possible trustcreating mechanisms for immigrants. It was found that the study programmes, English as a second language classes, computer classes, and civics classes provided opportunities not only for developing language skills and knowledge, but also for developing informal contacts and generating trust among students, and creating trust in the library as an institution. Vårheim (under review) looked at variation in trust among Mexican immigrants to the United States - the majority of whom were illegal immigrants -enrolled in library programmes. The study found evidence of increased trust levels, especially trust in the library as an institution, and trust in library users in 
general. However, strangers outside the library were far less trusted. The present paper expands upon these studies examining whether and how library programmes for immigrants create trust in a European and Norwegian context. In this study, the trustcreating potential of library programming for refugees in a Norwegian public library is examined. Case studies across a variety of countries and public libraries are needed to validate whether and library programming creates trust and social capital.

The paper widens the scope of research in this field by studying the supporting role of a Norwegian public library for a compulsory government introductory programme to Norwegian language and society for refugees. It can be argued that the way immigrants are welcomed to their new home country can enhance integration processes and levels of trust, and that the way introductory programmes are designed and conducted has an impact. In this article, it is primarily the role of a public library in cooperating with the introductory programme that is studied. How does library programming for these students facilitate their learning and integration into Norwegian society? One indicator of societal integration would be generalized social trust - i.e. trust in strangers. To evaluate the programmes, their success in creating trust among students is key, both regarding language acquisition and integration into Norwegian society. Trust in the programmes, trust in programme-related library services, and trust in the library as an institution can be instrumental both regarding the effectiveness of the introductory programme and of library services, as well as speed up the integration process in Norwegian society and, over time, build levels of generalized trust.

\section{Data and method}


The effects of library programming on social trust have received little scholarly attention (Vårheim, 2011; Vårheim, under review). Even less is known about the effects on trust of library programming for immigrants. In addition, as the compulsory introductory programmes for refugees have only recently been introduced, little is known about how library programming works for these students. This study takes an initial step in remedying this situation by describing how library programming for introductory course students was organized and how it operated in a public library in a city in North Norway. The population was approx. 70,000 inhabitants.

It was concluded that the most appropriate form of data collection for this explorative research requiring in-depth study was unstructured interviews. Explorative studies are but one step in the process of theory development. The results from this study are thus seen as possible input in a wider theory building process (George and Bennett, 2005; Gerring, 2007). A single-case study of library programming for immigrants prepares the ground for further case studies aiming at hypothesis testing, aka analytical (theoretical) generalization, and/or statistical generalization from quantitative survey data (Yin, 1989; Gerring, 2007). The main purpose for the research was to explore and develop the understanding of whether public library programmes can generate trust. Interviewees were selected for collecting as much information as possible rather than representativeness. In this context, a lower number of individual informants are reasonable. Nevertheless, students were chosen to show variation in terms of student or former-student status, which also reflect length of stay in Norway, variation in ethnic group membership, in age and gender. The students were found thanks to the library. 
Two librarians and eight students were interviewed as part of the study. The students were both former and current students on the programme; most had refugee status, while one was asylum-seeker. They came from Iraq, Afghanistan, Palestine, Morocco, Ethiopia, Eritrea, and Sri Lanka, and half of the students interviewed were women. The students were asked to evaluate the services of the library and the programming, in particular what they thought of the usefulness of the library as an appendix to the language and society classes, and whether their participation in the programme had increased their trust in the public library, in other library users, and in people in general (see Appendix for the interview guide). The librarian working directly with the programmes who was jointly employed in the library and as a teacher on the introductory programme for refugees, and the head of programming programming in the library were interviewed. Interviews were conducted in September and December of 2010 and took place in a city library meeting room. The interviews were recorded and notes were taken.

\section{Library use and library programmes}

Refugees who have residence permits are required to participate in a two-year introductory programme to Norwegian society consisting of a minimum of 300 hours (and if more is required, a maximum of 3,000 hours) of classes on Norwegian language and society (VOX, 2007; The Ministry of Children, Equality and Social Inclusion, 2009). Asylum-seekers (refugees applying for residence permits) are offered 250 hours of Norwegian language instruction (IMDI, 2011: 41). 
The students from the introductory programme were introduced to the public library by a specialist librarian working in the library who was also a teacher on the introductory programme. The librarian organized a variety of programmes for the students and other immigrant library patrons. Prominent among these were a women's reading group and a homework service in the library conducted by the local branch of the Red Cross. Combining the role of librarian and teacher made the planning and conducting of library programmes for the students easier and more targeted (Interview). The teacher/librarian introduced the students to the library, to the library programmes, and the students benefited from already knowing someone working in the library, that is, their teacher. The exchange of relevant information about the refugee user group enabled the library to prepare for the new users. For example, when the arrival of a group of young asylum-seekers was expected in town, the library was able to adjust its collection accordingly (Interview). The formalized cooperation with the introductory programme made it easier to have classes introducing the services of the library to the students, to prepare materials, and to arrange book talk sessions. Direct knowledge of students' educational levels, Norwegian language proficiency, age, gender, and cultural background, obtained from the introductory programme makes the planning of services more efficient. The impression of both the librarians interviewed was that refugees and asylum-seekers use the library far more than the average Norwegian population, and this use is mostly without difficulties.

The students, and especially the men, were heavy library users, and the computers in particular were used by the immigrants. The men used the computers/Internet more, read, socialized with friends, and played games, while the women brought their children to the library to take advantage of targeted programmes 
such as storytelling. The women also participated in storytelling sessions in the children's department. Sometimes the mothers themselves told stories in their own language. Some asylum-seekers spent the whole day in the library and immigrant youth frequently arranged to meet in the library. (Interviews, Librarian 1 and Librarian 2). Some students helped in the library as interpreters. The close connection between the introductory programme and the library lowered the barriers to practicing Norwegian in the library. The women participating in the women's reading group saw this as a great opportunity for practicing Norwegian. Former introductory-programme students used the library much less than the current students, about every other week according to a former male student, while the women participating in the reading group came once a week.

The immigrants interviewed were mostly between 20 and 30 years' old. Five were recent arrivals and students in the introductory programme, while one was an asylum-seeker and did not participate in the introductory programme, but did undertake Norwegian classes. The five had been in Norway between one and two years. Three of the interviewees had been in Norway for seven to twelve years and were former introductory-programme students. Two of the former female students participated in the women's reading group. The students still participating in the introductory programme tended to make significant use of the library: from two to three times a week, to every day. And their visits were of considerable length - from two hours till most of the day. They all made use of the homework services provided by Red Cross volunteers, and they spoke highly of this service: "Homework service, thank you very much! I want it every day [it is provided three afternoons a week].” Much of the activity is focused on schoolwork. The library was used primarily as a place for study: "I can work in the library, not at home, [when I see that] other people 
work in the library, then I can work, it gives energy, and seeing others gives energy". The size of the library space compared to space at home were also emphasized: "I can change places for work."

\section{Meetings in the library}

As might be expected, the students meet fellow students in the library, but they also meet other friends. They rarely speak with people they do not know. However, one student explained that she is not afraid of speaking with Norwegians. The asylumseeker said that:

"We only meet each other, we fear being rejected, because coming from countries with less education we feel embarrassed, do not know how to communicate", why should they be interested in you?"

Most of the practice the students got speaking in Norwegian was connected to formal settings, speaking with library staff and in the women's reading group. This is very different for the group of former students who were more fluent in Norwegian. This group frequently spoke with Norwegians in the library: "I may speak with unknown people about library relevant topics". Another former student said that "I talk with people in the library - 'What book are you reading? Have you read this?"' In contrast, outside the library they mostly only exchange greetings with Norwegians: "People at bus stops, are they afraid of us? Some are OK, and it is easier to speak with older people!" One student stated he had tried to make contact with Norwegians: "People are nice, but then they stop. I have a different cultural background, difficult to 
make contact; I very much want to have contact, then you feel that you are alive, I feel good."

\section{Trust}

The students in general put great trust in the public library as an institution. Most also referred to the library as a safe place. Their trust in the library had increased over the time period they had participated in the introductory programme. Most students had little knowledge of public libraries from their home countries. Two of the students did, however, sometimes felt unsafe in the library because of conflict within groups of refugees from the same country.

The trust in the library was rooted in the fact that it was perceived as "for everyone from any country", i.e., it is an universal institution, it is a "cultural center and information center". It was also described as "good value for money" and "the safest of all places"; "it is a very good idea, people can develop and learn."

In spite of some reservations regarding fellow nationals, the students largely trusted other library users. Moreover, the trust in fellow library users was higher than for other unknown people and even higher than for neighbors. The reason for trusting library users more than strangers in general was that library users "are interested in reading, interested in the same as me." Overall, the students had little trust in strangers outside the library. There was a tendency that newcomer students were more trusting towards neighbors and strangers than former students, while there was little distinction regarding trust in the library and in library users. 
The programme librarian described the students as very trusting in everything Norwegian when first arriving in Norway. Faced with bureaucracy, the difficulty of learning Norwegian, delays in obtaining employment, the difficulty of speaking with natives, and mistrust inside some refugee groups, the initial "big happiness" fades and the level of generalized trust seems to fall. However, they are in a relatively peaceful city, there are no segregated ethnic communities, the library has a central location, and it is perceived as offering a helping hand in this period of transition between lack of attachment and integration in Norwegian society: "The library becomes their second home; It is viewed as a helper, it is free, and it is possible to get things done there, the knowledge of Norwegian increases, and it is spacious."

The students spent a substantial amount of time in the library, and it was regarded very positively. One student said: "The library is my life". Another student had bought an apartment opposite the public library to be able to spend as much time as possible in the library.

Even so, according to the programme librarian, the library can always do more to create trust. A successful programme which had the potential to be expanded, involved offering the students work in the library as a way of practicing Norwegian language skills while at the same time helping to serve their own minority groups. In addition to more resources to serve more groups, the employment of librarians with immigrant backgrounds might be another strategy for facilitating integration, as stated by the programme librarian.

\section{Discussion}


Current and past students in the introductory programme were all frequent library users. Although usage reduces for former students, the library still seemed to play a significant role in their lives. The introduction to the public library and library services that forms part of the introductory programme to Norwegian language and society had forged strong links between the students and the public library. Formalized cooperation between the library and the introductory programme had made this possible. The public library had, through cooperation with and working with local community voluntary associations, created a women's reading group organized and lead by the immigrant librarian, and had put in place a homework service run by the Red Cross, which were the two formal library services strongly connecting the refugees to the library, in addition to general library services that this user group also made frequent use of. From interviews with the former introductoryprogramme students it is apparent that the close relationship with the public library was continued after graduation from the introductory programme.

Trust in people in general is an indicator of the health of a society and an indicator of integration between societal groups. The students trusted the library institution and most trusted other library users, while trust in unknown people outside the library was low or non-existent. Findings from research on trust patterns of Mexican immigrants to the United States participating in library language and society programmes also report high trust within the context of the library (Vårheim, 2011; Vårheim, under review). Likewise, consistent with the present findings, generalized trust ahead of programmes were low and still were low after attending the programmes.

The trust created towards the library institution and other library users can be a starting point for creating generalized trust outside of the library. However, the fact 
that former students are less trusting towards strangers, compared with current students, is perhaps worrying in terms of the integration of immigrants in Norwegian society. The lowered trust could, however, be the result of the wearing off of the "honeymoon effect" indicating that the trust patterns of newcomers are unstable, and that they need some time in the host country before core attitudes as social trust are stabilized.

Further research is needed to find out whether the pattern of low trust holds for future classes and future former students, and whether former student trust levels continue to stay low over time. Extrapolating from Europe-wide studies regarding immigration and trust, dealings with fair public institutions over time should increase generalized trust for first-generation immigrants, and for second-generation immigrants, the level of generalized trust could reach almost that of the native population (Dinesen, 2010). This also applies for groups emigrating from low-trust nations. On the other hand, the US experience shows that trust levels for immigrants coming from low-trust societies tend to remain low, at least over several generations (Algan and Cahuc, 2010; Klesner, 2003).

In spite of the mixed results, the trust the interviewees - both current and former students - have in the public library reveals the trust-creating potential of the library. It can be argued that it is likely that trust in libraries and trust in library users have general trust generating effects, but that these effects can be offset by other factors relating to, for example, negative experiences in school and the workplace, and recurrent episodes of informal face to face interaction characterized by reluctance on behalf of the majority population and interpreted as indifference or worse as hostility by the immigrants. However, the European wide data including Norway, show that in expanded timeframes covering both 1 st and 2 nd generation immigrants 
trust levels rise, and that for the second generation they nearly reach the general trust levels of natives (Dinesen, 2010). In view of this, the question posed in this article can be rephrased into whether it is possible that public libraries through programme activity for immigrants can contribute in increasing the speed of trust creating processes. Public libraries are one of the first public institutions refugees meet, and as such can have an early impact on trust. Still, the possibility of zero effect on generalized trust must be considered.

Students place high trust in the institution of the public library, have contact with unfamiliar library users, and also trust unknown users in general. The mechanisms creating this trust in library phenomena are related to library programming and knowledge and experience of of the library institution. Institutional trust spills over into ascribing trusting properties to library users in general. They are seen as people with good intentions, in that they are perceived to be visiting the library for the same educative reasons as the students themselves. Related to this, the public library is seen as a safe setting for contact with unknown people, i.e., unknown library users.

In the literature on the effects of fair public institutions on trust, the mechanisms for creating trust have only sparingly been described empirically. By studying these mechanisms at work in, for example, public libraries, more will be known about what is happening at an individual level, which will contribute to the grounding of the institutional perspective on the creation of generalized trust. Features of openness and inclusiveness characterize the public library institution, and by providing a framework for fulfilling individual projects, libraries could make particularly suitable spaces for creating institutional trust. 
At the same time this institutional trust combined with their emulation of public squares, make libraries unique settings for creating contact between unknown users. This is different from most other public institutions, and make public libraries places for trust creation through informal social contact as well as through their institutional rationale as providers of information represented by the various formats and technologies of documents. Most contact reduces prejudice, while libraries in addition share widely recognized contact-facilitating properties: [e]qual group status within the situation; common goals; intergroup cooperation; and the support of authorities, law, or custom" (Pettigrew, 1998: 65). Patrons share the same status when within public libraries; they more or less have common purposes; contact between users increases over time; and the common public space of the library is upheld by government, law, and custom.

\section{Conclusion}

This paper reports on the effect of library programming in one public library on social trust and social capital among refugees. The library programmes studied were sequels to the mandatory introductory programme on Norwegian language and society in that the library programme participants are introductory programme students.

Students were introduced to library programmes providing homework support and a reading group offering language practice. While enrolled in the introductory programme, students were almost daily library users. Following the completion of the introductory programme, the frequency of use was reduced, but the immigrants were 
still among the most dedicated library patrons. The library was considered important in the students' lives.

From the literatures on social trust and public institutions; on social contact; and on studies of public libraries, immigrants, and social trust; it can be expected that library programmes for refugees have potential for generating generalized trust, that is, trust in strangers. This expectation was not wholly confirmed in the present study, and it seems in need of qualification. Trust in fellow library users and trust in the institution of the public library were increased, while change in the trust in people in general appeared to rise in a neglible degree during the programme period. Indeed, following the completion of the programmes generalized trust was reduced compared to the immediate post-programme situation. This reduction in trust may pose an important question for further study of the effects of public libraries for generalized trust as well as regarding the effects for trust of public institutions as such. Positive long-term effects on generalized trust were expected based on findings from earlier social capital research, but is this the case for libraries? This article indicates that at least for the first couple of years in the host country the initial "honeymoon effect" is wearing off.

Still, the question of the impact of public libraries on trust remains. The library programmes introduced the students to activities directly relevant to their studies in language and society, and the library was considered by most students to be a safe place. Even when the feeling of safety was highly in doubt, the library was still frequented and both the library institution and unknown library users were trusted. Contacts were made also with unknown patrons. Given all this, and what is known about changes in the patterns of general trust among immigrants in a longer time frame than used in this study, the findings indicate that trust levels will increase given sufficient time and that public library programmes enhance trust creating processes. 
The post-intoductory programme decline in generalized trust could be almost inevitable given the stress of everyday life that students are confronted with after the completion of the introductory programme. More elaborate studies following programme students over time are needed to find out, and whether the increasing trust kevels found in European surveys are trustworthy

Complementing earlier studies, this paper shows that public library programmes for immigrants contribute to the creation of social trust within the walls of the library, but generalized trust remains low while the students still participate in the programmes. However, over some time, after attending programmes, generalized trust seems to decrease among former students. The long term trust effects of the library programmes have not been studied, and this question is highly in need of further research. Still, without specific knowledge on the long-term effect of public library programming on generalized trust, public libraries can play an important part in facilitating and speeding up trust-creating processes by creating trust in the community of the library itself, and by providing information that increases the ability of the refugees to navigate and cope in Norwegian society, and thus make integration processes less traumatic for immigrants and natives. Replication of the results in studies of immigrants' library use and trust levels over time, and also covering immigrants that have not attended the introductory programme and library programmes, could tell more about the overall role of libraries in trust creation for immigrants. Including a control group of non-users would widen and strengthen the theoretical implications of findings considerably.

\section{Acknowledgments}


I thank the interviewees for their participation and their time. Two anonymous reviewers are thanked for helpful comments. Remaining weaknesses rest solely with the author. Funding has been received in part from the Research Council of Norway through the research project PLACE (Public Libraries as Arenas for Citizenship).

\section{Notes}

1. These data have been collected by the research project PLACE ('Public Libraries as Arenas for Citizenship") at Oslo University College, the University of Tromsø, and Oslo School of Architecture and Design.

\section{References}

Aabø S, Audunson RA and Vårheim A (2010) How do public libraries function as meeting places? Library \& Information Science Research 32(1): 16-26.

Alesina A and La Ferrara E (2000) Participation in heterogeneous communities. Quarterly Journal of Economics 115(3): 847-904.

Alesina A and La Ferrara E (2002) Who trusts others? Journal of Public Economics 85(2): 207-234.

Algan Y and Cahuc P (2010) Inherited trust and growth. American Economic Review 100(5): 2060-2092.

Audunson RA, Essmat S and Aabø S (2011) Public libraries: A meeting place for immigrant women? Library \& Information Science Research 33(3): 220-227. 
Caidi N and Allard D (2005) Social inclusion of newcomers to Canada: An information problem? Library \& Information Science Research 27(3): 302324.

Coffe H and Geys B (2006) Community heterogeneity: A burden for the creation of social capital? Social Science Quarterly 87(5): 1053-1072.

Costa DL and Kahn ME (2003) Understanding the American decline in social capital, 1952-1998. Kyklos 56(1): 17-46.

Cox E, Swinbourne K, Pip C and Laing S (2000) A safe place to go: Libraries and social capital. Sydney: University of Technology, Sydney, and the State Library of New South Wales, 53. Available at: http://www.sl.nsw.gov.au/services/public_libraries/docs/safe_place.pdf.

Delhey J and Newton K (2005) Predicting cross-national levels of social trust: Global pattern or Nordic exceptionalism? European Sociological Review 21(4): 311327.

Dinesen PT (2010) When in Rome, do as the romans do: The acculturation of generalized trust among immigrants in Western Europe. International Migration Review 44(3): 697-727.

Dinesen PT (2011) Where you come from or where you live? Examining the cultural and institutional explanation of generalized trust using migration as a natural experiment. European Sociological Review.

Elbeshausen H and Skov P (2004) Public libraries in a multicultural space: A case study of integration processes in local communities. New Library World 105(3/4): 131-141.

Fisher KE, Durrance JC and Hinton MB (2004) Information grounds and the use of need-based services by immigrants in Queens, New York: A context-based, 
outcome evaluation approach. Journal of the American Society for Information Science and Technology 55(8): 754-766.

George AL and Bennett A (2005) Case studies and theory development in the social sciences. Cambridge, Mass.: MIT Press.

Gerring J (2007) Case study research : principles and practices. New York: Cambridge University Press.

Höglund L and Wahlström E (2009) Användningen och attityderna. En rapport om allmänhetens användning av och syn på folkbibliotek baserad på SOMundersökningen 2007 [Use and attitudes: a report on the public use of and attitudes towards public libraries based on the SOM-survey 2007. Svensk Biblioteksförening. Available at: http://bada.hb.se/handle/2320/5948.

IMDI (2011) iFacts 2011: Fact booklet about immigrants and integration. Oslo: The Norwegian Directorate of Integration and Diversity. Available at: http://www.imdi.no/Documents/BrosjyrerHefterHaandbok/iFACTS 2011.pdf. Johnson CA (2010) Do public libraries contribute to social capital? A preliminary investigation into the relationship. Library \& Information Science Research 32(2): 147-155.

Johnson CA (2012) How do public libraries create social capital? An analysis of interactions between library staff and patrons. Library \& Information Science Research 34(1): 52-62.

Johnson CA and Griffis MR (2009) A place where everybody knows your name? Investigating the relationship between public libraries and social capital. Canadian Journal of Information \& Library Sciences 33(3/4): 159-191. 
Klesner JL (2003) Political attitudes, social capital, and political participation: The United States and Mexico compared. Mexican Studies/Estudios Mexicanos 19(1): 29-63.

Kumlin S and Rothstein B (2005) Making and breaking social capital: The impact of welfare-state institutions. Comparative Political Studies 38(4): 339-365.

Kumlin S and Rothstein B (2010) Questioning the new liberal dilemma: Immigrants, social networks, and institutional fairness. Comparative Politics 43(1): 63-80.

Marschall MJ and Stolle D (2004) Race and the city: Neighborhood context and the development of generalized trust. Political Behavior 26(2): 125-153.

Pettigrew TF (1998) Intergroup contact theory. Annual Review of Psychology 49: 6585.

Pettigrew TF and Tropp LR (2011) When groups meet: The dynamics of intergroup contact. New York: Psychology Press.

Pettigrew TF, Tropp LR, Wagner U and Christ O (2011) Recent advances in intergroup contact theory. International Journal of Intercultural Relations 35(3): 271-280.

Putnam RD (2007) E Pluribus Unum: Diversity and community in the twenty-first century. The 2006 Johan Skytte Prize Lecture. Scandinavian Political Studies 30(2): 137-174.

Putnam RD, Feldstein LM and Cohen D (2003) Better together: Restoring the American community. New York: Simon \& Schuster.

Rothstein B and Stolle D (2008) The state and social capital: An institutional theory of generalized trust. Comparative Politics 40(4): 441-459. 
Stolle D, Soroka S and Johnston R (2008) When does diversity erode trust?

Neighborhood diversity, interpersonal trust and the mediating effect of social interactions. Political Studies 56(1): 57-75.

The Ministry of Children, Equality and Social Inclusion (2009) Introductory programmeme and Norwegian language instruction for newly arrived immigrants. Available at:

http://www.regjeringen.no/nb/dep/bld/ryddemappe/temainnhold/introductoryprogrammeme-and-norwegian-lan.html $? \mathrm{id}=477798$.

Uslaner EM (2010) Segregation, mistrust and minorities. Ethnicities 10(4): 415-434.

VOX (2007) Vox Internett - Immigrant integration. Nasjonalt fagorgan for

kompetansepolitikk. . Available at: http://www.vox.no/no/globalmeny/English/Immigrant-integration/.

Vårheim A (2007) Social capital and public libraries: The need for research. Library \& Information Science Research 29(3): 416-428.

Vårheim A (2011) Gracious space: Library programming strategies towards immigrants as tools in the creation of social capital. Library \& Information Science Research 33(1): 12-18.

Vårheim, A. (in press). Trust in libraries and trust in most people: Social capital creation in the public library. Library Quarterly, 84.

Vårheim A, Steinmo S and Ide E (2008) Do libraries matter? Public libraries and the creation of social capital. Journal of Documentation 64(6): 877-892.

Yin RK (1989) Case Study Research: Design and Methods. Newbury Park, CA: Sage. 